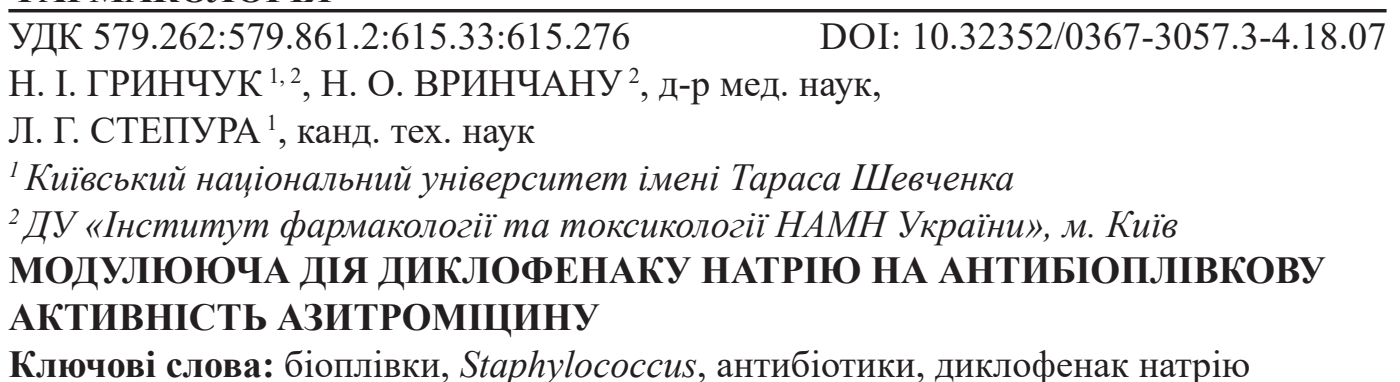

\author{
N. I. HRYNCHUK ${ }^{1,2}$, N.O. VRYNCHANU ${ }^{2}$, L. G. STEPURA ${ }^{1}$ \\ ${ }^{1}$ Taras Shevchenko National University of Kyiv \\ ${ }^{2}$ SI «Institute of Pharmacology and Toxicology of the National Academy of Medical Sciences of \\ Ukraine», Kyiv
}

\title{
INFLUENCE OF DICLOFENAC SODIUM ON ANTIBIOFILM ACTIVITY OF AZITHROMYCIN
}

Key words: biofilms, Staphylococcus, antibiotics, diclofenac sodium

Протягом останніх років у всьому світі спостерігають значне зростання стійкості збудників позалікарняних і нозокоміальних інфекцій до дії антимікробних препаратів. Одним із мікроорганізмів, здатних зумовити інфекційні процеси, є Staphylococcus epidermidis. Епідермальний стафілокок - непатогенний мікроорганізм, який у людей 3 імунодефіцитними станами здатен зумовити як гострі, так і хронічні запальні процеси, останні - завдяки можливості плівкоутворення. S. epidermidis зумовлює ендокардити, інфекції серцевих клапанів та видільної системи, інфекції у новонароджених тощо. Найчастіше цей збудник виявляють у пацієнтів із протезами клапанів серця, суглобів, у осіб, яким тривалий час застосовують венозні та сечовивідні катетери, а також ендотрахеальні трубки. Для лікування пацієнтів із запальними процесами, зумовленими епідермальним стафілококом, застосовують препарати різних груп, серед яких і $\beta$-лактамні антибіотики. При визначенні чутливості S. epidermidis до $\beta$-лактамів отримано дані, які свідчать про поширення резистентності серед цих мікроорганізмів. Так, встановлено, що серед виділених штамів лише $40 \%$ виявилися чутливими до цих препаратів, а кількість метицилінрезистентних штамів у 2 рази перевищує таку Staphylococcus aureus [1].

Одним із проявів резистентності є формування мікроорганізмами біоплівок структурованих мікробних спільнот, оточених біополімерним матриксом, які утворюються внаслідок адгезії мікроорганізмів до біотичного чи абіотичного субстрату. Існування бактерій у біоплівці забезпечує їм чисельні переваги порівняно з ізольованими клітинами. Особливо важливо, що бактерії в біоплівках характеризуються підвищеною стійкістю до дії агресивних речовин, факторів імунного захисту та антимікробних препаратів. Мікроорганізми у складі біоплівки здатні виживати при таких високих концентраціях, які не можуть бути досягнуті в організмі людини при стандартних терапевтичних дозах [2]. Протидію антимікробним засобам забезпечує мікробній спільноті структура, а саме кластерна будова та наявність персистуючих клітин. Значна роль у формуванні резистентності належить також і механізмам міжклітинної комунікації quorum sensing (QS). Використовуючи QS, мікроорганізми здійснюють внутрішньовидову, міжвидову комунікацію, взаємодіють із вищими еукаріотами. Завдяки системі QS мікроорганізми корегують щільність популяції біо(с) Колектив авторів, 2018 
плівки та забезпечують вивільнення поверхневих клітин, які колонізують нові біотичні та абіотичні поверхні, призводять до хронізації інфекційного процесу.

У зв'язку з цим, нині виникає потреба у нових підходах до лікування хронічних гнійно-запальних процесів, зумовлених біоплівковими формами бактерій. Одним із шляхів вирішення проблеми є сумісне застосування антимікробних засобів із препаратами різних фармакотерапевтичних груп. У цьому плані на увагу заслуговують нестероїдні протизапальні засоби (НПЗ3), які широко використовують у клінічній практиці. НПЗ3 застосовують більше тридцяти мільйонів людей у світі [3]. Окрім первинного фармакологічного ефекту, деякі нестероїдні протизапальні засоби виявляють і вторинну дію - інгібують ріст та розмноження мікроорганізмів $[4,5]$. Так, до дії НПЗ3 виявляє чутливість $S$. aureus, МІК диклофенаку натрію відносно золотистого стафілокока - 1465 мкг/мл, ібупрофену - 952 мкг/мл, кетопрофену - 1 607,5 мкг/мл [6]. Однак зазначені концентрації значно перевищують терапевтичні і не можуть застосовуватися за новим призначенням як антибактеріальні засоби. Разом з тим, у літературі $є$ дані щодо позитивного їх впливу на специфічну активність антибіотиків, застосування препаратів у терапевтичних концентраціях або нижче змінює чутливість мікроорганізмів до дії антимікробних препаратів. Так, згідно 3 [7], диклофенак натрію здатен як підвищувати чутливість мікроорганізмів до антибіотиків, так і знижувати, зумовлюючи виникнення фенотипової резистентності до антимікробних препаратів.

Мета роботи - встановити антибіоплівкову дію азитроміцину у разі сумісного застосування 3 нестероїдним протизапальним засобом - диклофенаком натрію відносно біоплівки Staphylococcus epidermidis.

\section{М ат ер і а ли т а ме тоди досліджен н я}

Антимікробні властивості азитроміцину (Азитроміцин (Azithromycin), субстанція, серія 1502000319, отримано від ЗАТ НВЦ «Борщагівський хіміко-фармацевтичний завод», Україна) і диклофенаку (Диклофенак-Дарниця (Diclofenac), розчин для ін’єкцій, виробництва ПрАТ «Фармацевтична фірма "Дарниця"», Україна) та вплив останнього на специфічну дію макролідного антибіотика відносно біоплівок клінічного штаму Staphylococcus epidermidis 2265 оцінювали за здатністю порушувати плівкоутворення та руйнувати сформовані (12-годинні, 1 - та 2-добові) біоплівки.

На першому етапі за загальноприйнятою методикою [8] визначали мінімальну інгібуючу концентрацію (МІК) азитроміцину відносно планктонних клітин S. epidermidis 2265. Діапазон концентрацій становив 0,007-4 мкг/мл. В експериментах використовували 1-добову культуру мікроорганізмів із кінцевою щільністю інокуляту $10^{6} \mathrm{KУО/мл.} \mathrm{Термін} \mathrm{інкубації} \mathrm{становив} 24$ год за $37{ }^{\circ} \mathrm{C}$. Отримані результати показали, що МІК азитроміцину відносно S. epidermidis 2265 - 0,25 мкг/мл, що свідчить про його чутливість до дії макролідного антибіотика.

Антибіоплівкову активність азитроміцину вивчали у концентраціях 0,5 та 5,0 МІК, що становило 0,125 мкг/мл та 1,25 мкг/мл відповідно. За концентрацію диклофенаку брали значення, що відповідає максимальній концентрації препарату у крові за умови внутрішньом'язового введення $\left(\mathrm{C}_{\max }=2,5\right.$ мкг/мл) [9].

Під час дослідження впливу диклофенаку натрію на специфічну антибіоплівкову активність азитроміцину препарати вносили в інкубаційне середовище одночасно, відносно сформованих біоплівок - на 12-ту годину, 1-шу та 2-гу добу експерименту. Термін інкубації становив 24 год за $37^{\circ} \mathrm{C}$. Дослідження виконували за стандартною методикою [10]. Кількість повторів експериментів - не менше трьох. Статистичну обробку даних здійснювали з використанням критерію Ньюмена-Кейлса (програма «StatSoft «Statistica 6.0»). 
Результати дослідження та обговорення

Отримані дані щодо впливу азитроміцину на плівкоутворення свідчать, що азитроміцин порушує формування біоплівки клінічним штамом S. epidermidis 2265 , інгібування становить за концентрації 0,5 МІК - 80,6\%, за 5,0 МІК - 86,4\% (рис. 1). Антибіоплівкову активність виявляє і диклофенак натрію, за терапевтичної концентрації (2,5 мкг/мл) пригнічення становить 67,0\%. У разі сумісного застосування азитроміцину та диклофенаку натрію антибіоплівкова активність макроліду знижувалася до 69,5\% (за 0,5 МIK) та 65,2\% (за 5,0 МIK).

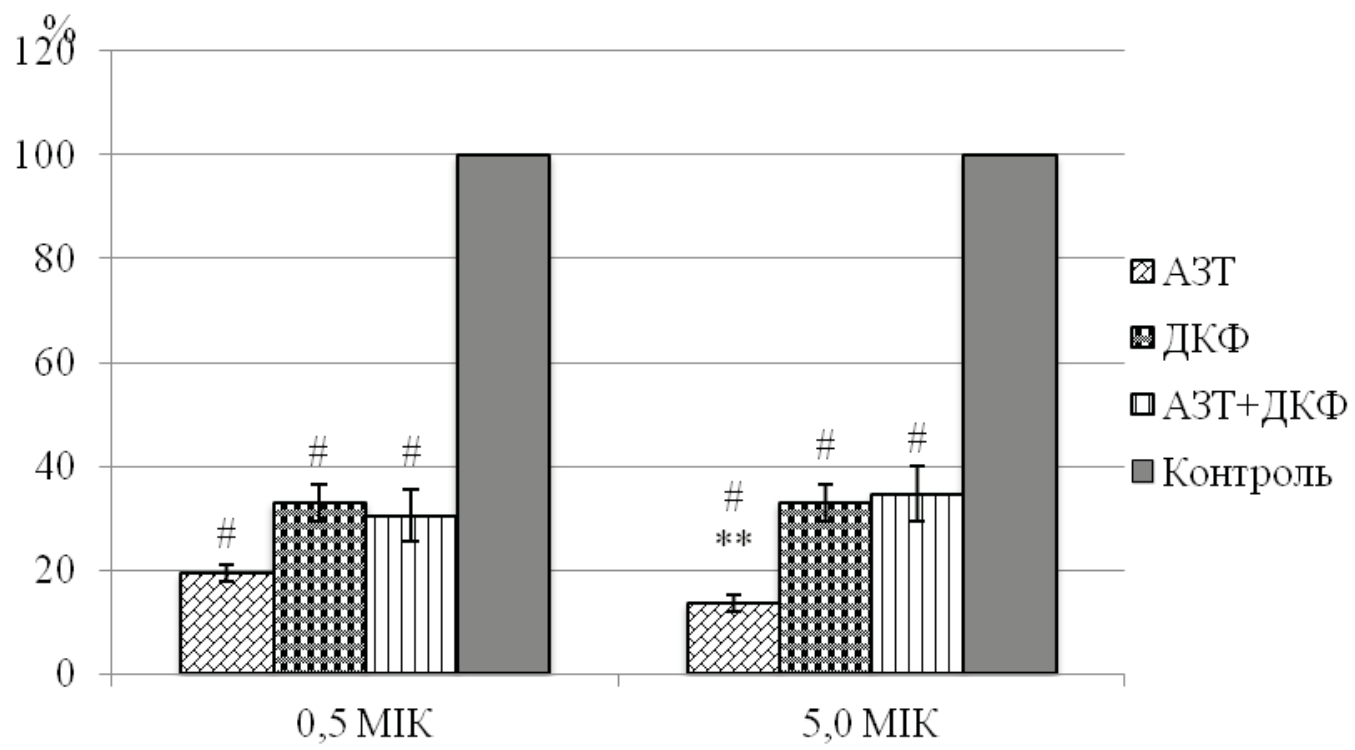

Рис. 1. Вплив диклофенаку на антибіоплівкову активність азитроміцину відносно S. epidermidis 2265 (\% утвореної біоплівки)

Пр и м і т к и: ${ }^{*}-p<0,05$ відносно 5,0 МІК АЗТ; ** $-p<0,05$ відносно 5,0 МІК АЗТ+ДКФ; $\#-p<0,05$ відносно контролю; \#\# - $p<0,05$ відносно 0,5 МІК АЗТ+ДКФ; АЗТ - азитроміцин; ДКФ - диклофенак.

Вплив азитроміцину та диклофенаку натрію на сформовані біоплівки досліджували відносно 12-годинних, 1- та 2-добових біоплівок S. epidermidis 2265. Отримані результати наведено на рис. 2-4.

Під час дослідження впливу на 12-годинну «молоду» біоплівку отримано дані, які свідчать, що антимікробний препарат азитроміцин у субінгібуючій концентрації не виявляв інгібуючого ефекту, біомаса сформованої біоплівки практично не відрізнялась від такої у контролі (рис. 2).

У разі збільшення концентрації антибіотика до 5,0 МІК деструкція біоплівки становить 28,9\%. Наявність в інкубаційному середовищі диклофенаку натрію не тільки не підвищує антибіоплівкову активність азитроміцину, але й стимулює іiі формування (збільшення біомаси біоплівки на 12,4\% порівняно з контролем).

Результати дослідження впливу азитроміцину та диклофенаку натрію на сформовану S. epidermidis 2265 1-добову біоплівку відображено на рис. 3.

Згідно з отриманими даними, азитроміцин не виявляє виразного впливу відносно 1-добової біоплівки за обох досліджуваних концентрацій (інгібуюча дія до $10,2 \%)$. 


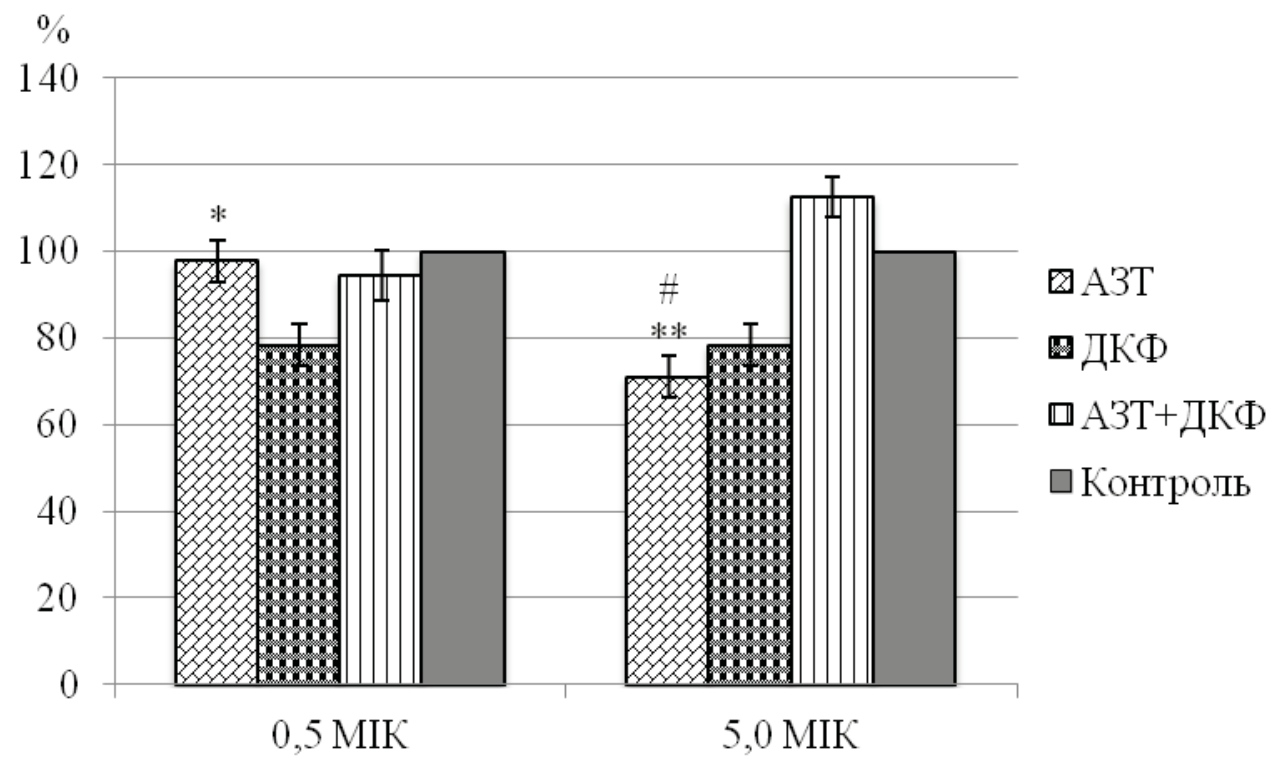

Рис. 2. Вплив диклофенаку на активність азитроміцину при дії на сформовані 12-годинні біоплівки S. epidermidis 2265 (\% біомаси біоплівки)

П р и м і т к и: * $-p<0,05$ відносно 5,0 МІК АЗТ; ** $-p<0,05$ відносно 5,0 МІК АЗТ+ДКФ; \# $-p<0,05$ відносно контролю; \#\# - $p<0,05$ відносно 0,5 МІК АЗТ+ДКФ; АЗТ - азитроміцин; ДКФ - диклофенак.

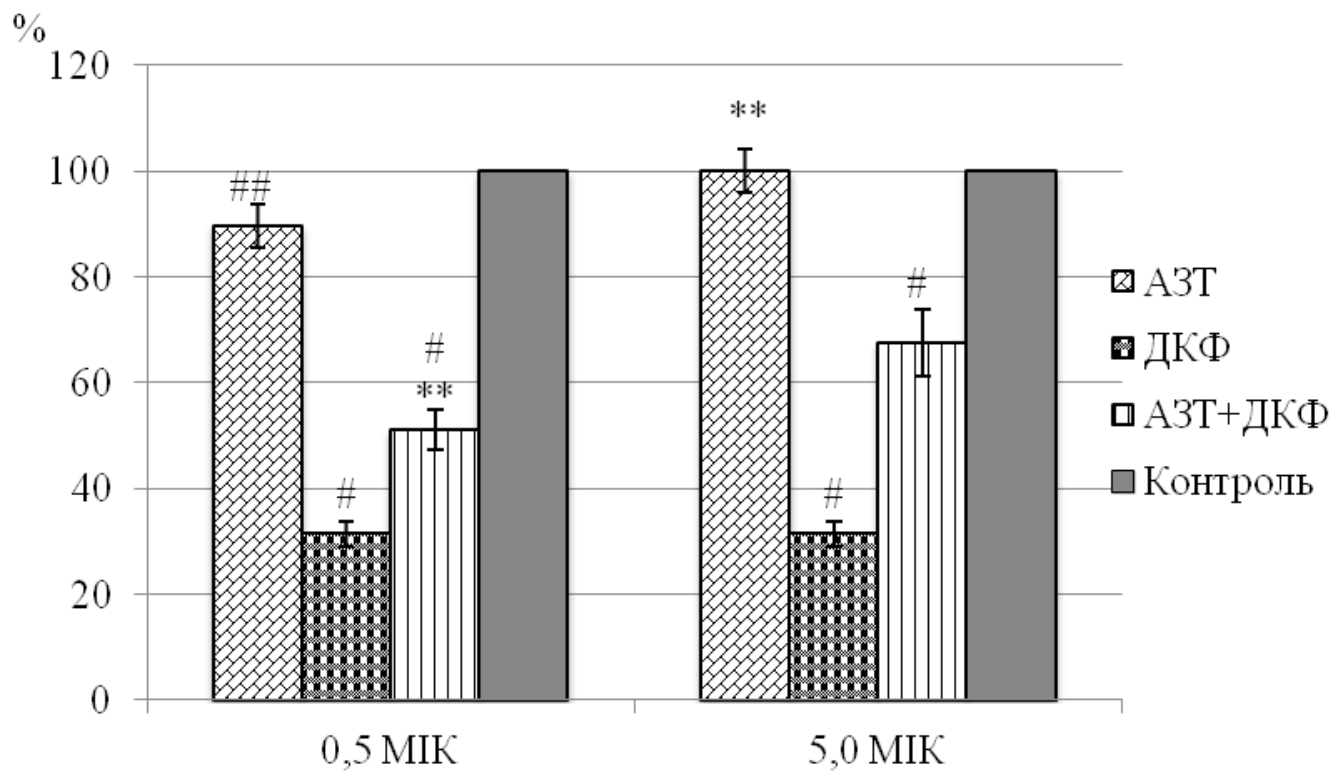

Рис. 3. Вплив диклофенаку на активність азитроміцину при дії на сформовані 1-добові біоплівки $\boldsymbol{S}$. epidermidis 2265 (\% біомаси біоплівки)

П р и м і т к и: * $-p<0,05$ відносно 5,0 МІК АЗТ; ** $-p<0,05$ відносно 5,0 МІК АЗТ+ДКФ; $\#-p<0,05$ відносно контролю; \#\# - $p<0,05$ відносно 0,5 МІК АЗТ+ДКФ; АЗТ - азитроміцин; ДКФ - диклофенак.

Значну антибіоплівкову активність виявляє диклофенак натрію, деструкція біоплівки у концентрації $\mathrm{C}_{\text {мах }}-68,5 \%$. Дослідженнями встановлено позитивний вплив нестероїдного протизапального засобу диклофенаку натрію на специфічну актив- 
ність макролідного антибіотика, антибіоплівова активність останнього зростає, про що свідчить біомаса біоплівки. Так, за 0,5 МІК азитроміцину біомаса біоплівки зменшується на 51\%, за 5,0 МІК - на 67,5\% (рис. 3).

Дослідження антибіоплівкової активності азитроміцину, диклофенаку натрію та вплив останнього на специфічну дію макроліду відносно 2-добових біоплівок S. epidermidis 2265 свідчать, що інгібуючий ефект антибіотика спостерігається лише за концентрації 5,0 МІК (інгібіція 14,8\%) (рис. 4). Диклофенак натрію не виявив значної інгібуючої активності (зменшення біомаси на 8,6\%) і практично не змінював антибіоплівкову дію азитроміцину (за 0,5 МІК). Слід відзначити, що сумісне використання азитроміцину у терапевтичних концентраціях (5,0 МІК) та диклофенаку натрію призвело до стимуляції плівкоутворення, про що свідчить біомаса біоплівки (збільшення на 10,6\% порівняно з контролем).

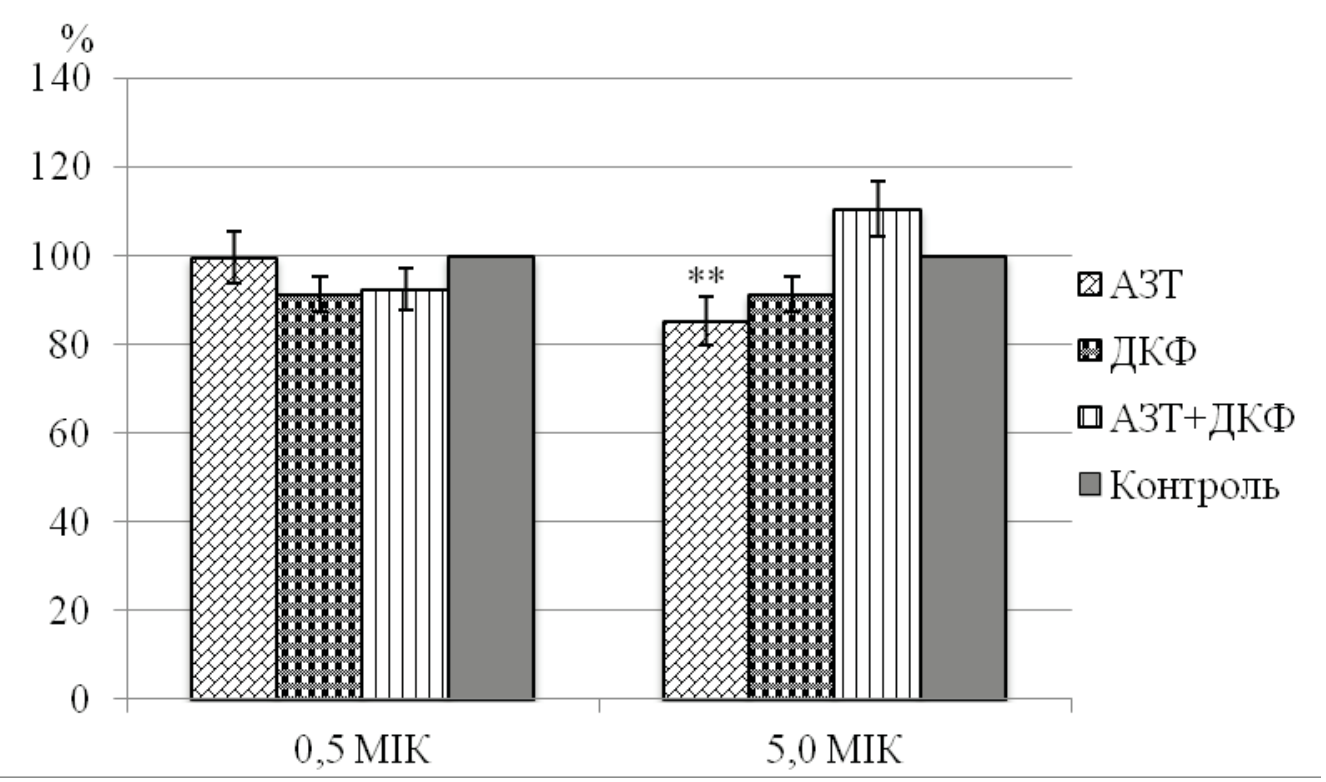

Рис. 4. Вплив диклофенаку на активність азитроміцину при дії на сформовані 2-добові біоплівки S. epidermidis 2265 (\% біомаси біоплівки)

П р и м і т к и: $*-p<0,05$ відносно 5,0 МІК АЗТ; ** $-p<0,05$ відносно 5,0 МІК АЗТ+ДКФ; \# $-p<0,05$ відносно контролю; \#\# - $p<0,05$ відносно 0,5 МІК АЗТ+ДКФ; АЗТ - азитроміцин; ДКФ - диклофенак.

Отже, мікроорганізми у складі 2-добової біоплівки виявляють стійкість до дії азитроміцину та диклофенаку натрію, позитивного впливу останнього на специфічну дію азитроміцину не встановлено.

\section{В и с н о в к и}

1. Встановлено, що азитроміцин в концентрації 0,5 МІК та 5,0 МІК порушує плівкоутворення S. epidermidis до абіотичної поверхні, інгібіція становить за 0,5 МІК - 80,6\%, за 5,0 МІК - 86,4\% (порівняно з контролем). Виразна антибіоплівкова дія притаманна диклофенаку натрію - інгібіція 67,0\%. У разі сумісного застосування азитроміцину та диклофенаку натрію антибіоплівкова активність макроліду знижувалася до 65,2-69,5\% залежно від концентрації.

2. Встановлено, що азитроміцин у досліджених концентраціях 0,5 та 5,0 МІК не виявляє виразного антибіоплівкового ефекту відносно 12-годинної біо- 
плівки. Наявність в інкубаційному середовищі диклофенаку натрію та азитроміцину стимулює формування біоплівки, спостерігається збільшення біомаси біоплівки на $12,4 \%$.

3. Отримані в експериментах дані свідчать, що азитроміцин не здійснює виразної антибіоплівкової активності відносно сформованої S. epidermidis 2265 1-добової біоплівки. Диклофенак натрію виявляє значну антибіоплівкову активність (деструкція у концентрації $\mathrm{C}_{\text {мах }}$ сягає $68,5 \%$ ) та сприяє підвищенню активності азитроміцину (за 0,5 МІК біомаса біоплівки зменшується на 51\%, за 5,0 МIК - на 67,5\%)

4. Дослідженнями встановлено, що найстійкішими до дії азитроміцину є 2-добові біоплівки. Сумісне застосування диклофенаку натрію та азитроміцину (у концентрації 5,0 МІК) супроводжується стимуляцією плівкоутворення (збільшення біомаси на 10,6\% порівняно з контролем), що може призвести до хронізації запального процесу і потребує подальших поглиблених досліджень.

5. Отримані результати дослідження свідчать про перспективність сумісного застосування азитроміцину з диклофенаком натрію лише на початкових стадіях (упродовж 1-ї доби) розвитку запальних процесів, зумовлених мікроорганізмами, оскільки він здатен порушувати утворення біоплівки, i, як наслідок, - запобігати хронізації процесу.

\section{С пи с ок ви к ор и с т а н ої лі т е р ат ури}

1. Божкова С. А., Краснова М. В., Полякова Е. М. та ін. Способность к формированию биопленок у клинических штаммов $S$. aureus и $S$. epidermidis - ведучих возбудителей ортопедической имплант-ассоциированной инфекции // Клин. микробиология антимикробной химиотерапии. - 2014. - № 2. - С. 149-156.

2. Чеботарь И. В. Биопленки Staphylococcus aureus: структурнофункциональные характеристики и взаимоотношения с нейтрофилами: Дис. ... д-ра мед. наук: 03.02.03. - Нижний Новгород, 2014. - 239 с.

3. Страчунский Л. С., Козлов С. Н. Нестероидные противовоспалительные средства [Електронний ресурс]. - Режим доступу: http:/www.antibiotic.ru/rus/all/ metod/npvs/npvs.shtml.

4. Rehab Mahmoud AbdEl-Baky, Sherein G. El-Gendy. Effectofnon-steroidalanti-in flammatory drugs and dexamethazone on the biofilm formation and expression of some adhesion-related genes of Candida albicans and Staphylococcus aureus // African J. Microbiol. Res. - 2016. - P. 694-707.

5. Res'lin'ski A., Da,browiecki S., Glowacka K. The impact of diclofenac and ibuprofen on biofilm formation on the surface of polypropylenemesh // Hernia. - 2015. - N 19. - P. 179-185.

6. Ahmed Mohsen, Alyaa Gomaa, Fatma Mohamed et al. Antibacterial, Anti-biofilm Activity of Some Non-steroidal Anti-Inflammatory Drugsand N-acetyl Cysteine against Some Biofilm Producing Uropathogens // American J. Epidemiol. Infectious Disease. 2015. - P. 1-9.

7. James T. Riordan Emailauthor, Jo Anne M. Dupre, Stephanie A. Cantore-Matyi et al. Alterations in the transcriptomeand antibiotics usceptibility of Staphylococcus aureus grown in the presence of diclofenac // Annals of Clinical Microbiology and 
Antimicrobials. - 2011 [Електронний pecypc] - Режим доступу: https://annclinmicrob.biomedcentral.com/articles/ 10.1186/1476-0711-10-30.

8. Некрасова Л. С., Свита В. М., Глушкевич Т. Г. та ін. Визначення чутливості мікроорганізмів до антибактеріальних препаратів: Метод. вказівки МВ 9.9.5-1432007. - К.: Офіц. вид., 2007. - 73 с.

9. Диклофенак-Дарниця. Інструкція для медичного застосування [Електронний ресурс]. - Режим доступу: http://mozdocs.kiev.ua/ likiview.php?id=39063.

10. O’Toole G. A. Microtiter dish biofilm formation assay // J. Vis. Exp. - 2011. N 47. - pii: 2437.

Надійшла до редакції 17 травня 2018 року.

Н. И. Грынчук ${ }^{1,2}$, Н. О. Врынчану ${ }^{2}$, Л. Г. Степура ${ }^{1}$

${ }^{1}$ Киевский национальный университет имени Тараса Шевченко

${ }^{2}$ ГУ «Институт фармакологии и токсикологии НАМН Украиныл», г.Киев

МОДУЛИРУЮЩЕЕ ДЕЙСТВИЕ ДИКЛОФЕНАКА НАТРИЯ НА

АНТИБИОПЛЕНОЧНУЮ АКТИВНОСТЬ АЗИТРОМИІЦИНА

Ключевые слова: биопленки, Staphylococcus, антибиотики, диклофенак натрия

А Н Н О Т А ЦИ Я

В настоящее время распространение биопленочных форм микроорганизмов создает большие трудности в медицинской практике, приводит к хронизации инфекционного процесса вследствие неэффективности антимикробной химиотерапии. Поэтому возникает потребность в новых подходах к лечению биопленочных инфекций, в частности в применении комбинаций препаратов различных фармакотерапевтических групп. Данные литературы свидетельствуют о перспективности нестероидных противовоспалительных средств, которые кроме первичного фармакологического действия способны проявлять антимикробные свойства, оказывать синергический эффект при совместном применении с антибиотиками.

Цель работы - установить специфическую антибиопленочною активность азитромицина при совместном применении с диклофенаком натрия.

Чувствительность клинического штамма S. epidermidis 2265 к действию азитромицина определяли методом серийных микроразведений и оценивали по показателю минимальной ингибирующей концентрации (МИК). Способность азитромицина, диклофенака натрия нарушать пленкообразование и влиять на сформированные стафилококком биопленки исследовали методом сорбции генцианвиолета на их структурах с последующей десорбцией в органический растворитель.

Результаты исследования показали, что азитромицин и диклофенак натрия способны нарушать формирование биопленок на абиотической поверхности. При исследовании влияния макролидного антибиотика на сформированные биопленки получены данные, свидетельствующие о невыразительной активности или ее отсутствии в зависимости от концентрации антибиотика. Значительную активность в отношении сформированных 1-суточных биопленок проявил диклофенак натрия (уменьшение биомассы до 68,5\%). Вместе с тем установлено, что диклофенак натрия способен стимулировать образование биопленки, способствовать увеличению 
ее биомассы, как 12-часовой так и 2-суточной (до 12,4\%). Экспериментально доказано, что при совместном применении азитромицина и диклофенака натрия антибиопленочная активность макролида снижалась до 69,5\% на этапе пленкообразования. Зарегистрировано также снижение активности макролида относительно сформированной 2-суточной биопленки S. epidermidis при применении в терапевтических концентрациях (увеличение биомассы на 10,6\% по сравнению с контролем). Антибиопленочная активность макролидного антибиотика усиливается только относительно 1-суточной биопленки.

Полученные результаты исследования свидетельствуют о перспективности применения азитромицина с диклофенаком натрия при острых гнойно-воспалительных процессах, поскольку последний способен нарушать пленкообразование и повышать специфическое действие антибиотика, и, как следствие, предотвращать хронизацию процесса. Вместе с тем вопрос о применении диклофенака натрия и азитромицина при хронических инфекционных процессах остается открытым и требует дальнейших углубленных исследований.

N. I. Hrynchuk ${ }^{1,2}$, N. O. Vrynchanu ${ }^{2}$, L. G. Stepura ${ }^{1}$

${ }^{1}$ Taras Shevchenko National University of Kyiv

${ }^{2}$ SI «Institute of Pharmacology and Toxicology of the National Academy of Medical Sciences of Ukraine», Kyiv

INFLUENCE OF DICLOFENAC SODIUM ON ANTIBIOFILM ACTIVITY OF AZITHROMYCIN

Key words: biofilms, Staphylococcus, antibiotics, diclofenac sodium

A B S T R A C T

Nowadays bacterial biofilms are the major problem in the medical practice, that can lead to chronic infections and decline of antimicrobial therapy efficacy. Therefore, combined use of drugs of various pharmacotherapeutic groups may offer significant benefits in the research of new ways of treatment infections associated with biofilms. The data of the literature shows that non-steroidal anti-inflammatory drugs have antimicrobial activity and they can be improved antimicrobial action of antibiotics.

The aim of the study was to establish specific antibiofilm activity of azithromycin in the combined treatment with diclofenac sodium.

Strain S. epidermidis 2265 susceptibility to azithromycin was evaluated by microdilution method and assessed by minimum inhibitory concentration (MIC). Action of azithromycin and diclofenac sodium on biofilm formation and preformed biofilms of $S$. epidermidis was determined by the crystal violet assay.

Our results of study have shown that azithromycin and diclofenac sodium reduced of biofilm formation to abiotic surface. Dose-depending low antibiofilm effect was found under treatment preformed $S$. epidermidis biofilms with macrolide antibiotic. Diclofenac sodium possessed antibiofilm activity against the preformed 1-day staphylococcal biofilms (reducing biomass 68.5\%). Also diclofenac sodium stimulated biofilms formation and increased biomass accumulation of preformed 12-hour and 
2-day staphylococcal biofilms to $12.4 \%$. The data obtained of experiments have shown that combined treatment with both azithromycin and diclofenac sodium lead to reduce activity of macrolide against biofilm formation (to 69.5\%) and S. epidermidis mature biofilms (2-day) at therapeutic concentrations (increasing biomass accumulation on $10.4 \%$ in comparison with controls). Antibiofilm activity of macrolide antibiotic become higher only against preformed 1-day biofilms.

The data obtained suggest the possibility of using of azithromycin with diclofenac sodium for treatment of acute purulent-inflammatory processes. Because of diclofenac sodium exhibited antibiofilm activity and increased the antibiotic specific activity, that lead to prevention of development of chronic infections. The issue of combined treatment of azithromycin with diclofenac sodium of chronic infections remains open and requires in-depth research.

Електронна адреса для листування завторами: natali72grynchuk@gmail.com 